Kiossoglou, K. A., Mitus, W. J., and Dameshek, W. (1965). Chromosomal aberrations in acute leukemia. Blood. The fournal of Hematology, 26, 610-641.

Loiodice, G., Rovetta, D. G., Bellicini, G., Callura, G., and Bergamo, F. (1970). Malformazioni multiple congenite in un bambino portatore di una anomalia cromosomica del gruppo $F(46 / X Y, 20-p)$, figlio di un soggetto, clinicamente sano, affetto da analoga malformazione cromosomica. Minerva Pediatrica, 22, 1084-1088.

Lucas, M., Kemp, N. H., Ellis, J. R., and Marshall, R. (1963/1964). A small autosomal ring chromosome in a female infant with congenital malformations. Annals of Human Genetics, 27, 189-195.

Millard, R. E., Lawler, S. D., Kay, H. E. M., and Cameron, C. B. (1968). Further observations on patients with a chromosomal abnormality associated with polycythaemia vera. British fournal of Haematology, 14, 363-374.

Reeves, B. R., Lobb, D. S., and Lawler, S. D. (1972). Identity of the abnormal F-group chromosome associated with polycythaemia vera. Humangenetik, 14, 159-161.

Sparkes, R. S., Carrel, R. E., and Wright, S. W. (1968). Partial F trisomy and parental chromosomes. Lancet, 2, 404-405.

Steele, M. W., Breg, W. R., Eidelman, A. I., Lion, D. T., and Terzakis, T. A. (1966). A B-group ring chromosome with mosaicism in a newborn with Cri du Chat syndrome. Cytogenetics, 5, 419-429.

\section{Bone Marrow Chromosomes in Fanconi's Anaemia}

Patients with the autosomal recessive syndrome, Fanconi's anaemia (FA), exhibit a high frequency of chromosome breakage and rearrangement in their cultured lymphocytes and skin fibroblasts (Swift and Hirschhorn, 1966). However, there is little published data on the aberration frequency in direct bone marrow preparations: in a recent review, bone marrow from 3 FA patients were reported to show no chromosome breaks while in 4 other cases $10 \%$ aberrant metaphases were found (Schroeder and Kurth, 1971). Bone marrow chromosome preparations differ significantly from those of lymphocytes in that the relatively short incubation time of marrow cells in vitro (approximately 2 hours) includes only a small fraction of a single cell cycle. Therefore findings in the marrow cells are important

Received 8 May 1972 because it is likely that these cells synthesized their DNA within the living patient. In contrast lymphocytes undergo one to two entire cell cycles in vitro $(48-72 \mathrm{hr}$ ) before chromosome analysis.

\section{Case Report}

We have studied a patient with Fanconi's anaemia whose clinical course has been described previously (Pochedly et al, 1971).

The propositus, an 8-year-old Negro male, was of subnormal size and weight for his age with a normocytic, normochromic anaemia and pancytopenia. Skeletal anomalies included small head circumference, Sprengel's deformity, Klippel-Feil anomaly, and short thumbs with flat thenar eminences. There was renal ectopia with both kidneys on the right side. Unusual features included growth hormone deficiencies and a marked elevation of haemoglobin F.

\section{Chromosome Studies}

Chromosome studies were done on direct bone marrow preparations following incubation of $1 \frac{1}{2} \mathrm{hr}$ with vincaleucoblastine, on peripheral blood lymphocytes incubated with phytohaemagglutinin for $72 \mathrm{hr}$ in vitro, and on skin fibroblasts cultivated in vitro for 7 weeks. The percentage of dividing cells (Table I) containing significant structural damage comprised $10 \%$ of the bone marrow cells, $26 \%$ of the fibroblasts, and $60 \%$ of the lymphocytes. There were, therefore, striking differences between populations of cells derived from a single individual.

Gaps, which were not recorded in the table of aberrations, were found in 4 marrow metaphases, 11 lymphocytes, and 7 of the cultured fibroblasts. Both gaps and breaks, chromatid and chromosomal, appeared to be distributed randomly within the chromosome groups with the exception that group A may have had slightly more than its share of breaks. No predilection for specific chromosomes or loci within chromosomes, such as points of secondary constriction, was apparent.

In this laboratory we have not obtained a series of marrow preparations from normal controls. Of 300 bone marrow cells from 15 patients, mainly suffering from leukaemia, 17 had chromatid or

TABLE I

CHROMOSOME ANALYSIS

\begin{tabular}{l|c|c|c|c|c}
\hline & \multicolumn{2}{|c|}{ Number of Cells } & \multicolumn{3}{c}{ Number of Aberrations } \\
\cline { 2 - 3 } & Examined & $\begin{array}{c}\text { With One or } \\
\text { More Major } \\
\text { Aberrations }\end{array}$ & $\begin{array}{c}\text { Chromatid } \\
\text { Breaks }\end{array}$ & $\begin{array}{c}\text { Isochromatid } \\
\text { Breaks }\end{array}$ & $\begin{array}{c}\text { Rearrangements } \\
\text { (rings, dicentrics } \\
\text { triradials, etc) }\end{array}$ \\
\hline Bone marrow & 50 & 5 & 4 & 1 & - \\
Lymphocytes & 50 & 30 & 16 & 24 & 9 \\
Skin fibroblasts & 100 & 26 & 13 & 15 & - \\
\hline
\end{tabular}


isochromatid breaks. Thus, the proportion of marrow cells with breaks in our FA patient $(10 \%)$ was greater than the average $(5 \%)$ found in individuals many of whom had diseases known to predispose to chromosome aberrations (Sandberg, 1966). A recent study of bone marrow chromosomes in a male control population found incidences of $3.19 \%$ and $0.55 \%$ for chromatid and chromosome aberrations respectively and a slightly greater than expected proportion of non-modal (hypodiploid) cells (O'Riordan, Berry, and Tough, 1970). The incidence of chromosome breakage in FA bone marrows may therefore be greater than in normals, but we have not been able to establish this conclusively.

\section{Conclusion}

The FA gene is of great interest because of its association with cancer and leukaemia in homozygotes and heterozygotes (Swift, 1971). If the bone marrow chromosomes are representative, it is unlikely that the inherited metabolic defect of Fanconi's anaemia is expressed in vivo primarily through frequent chromosome breaks and rearrangements. The nature of this genetic defect might be elucidated if we could learn what factors are responsible for the increase in chromosome aberrations in cell cultures in vitro from patients with Fanconi's anaemia.

\section{Summary}

The chromosomes of bone marrow cells from a patient with Fanconi's anaemia showed a lower aberration frequency than that of either lymphocyte or fibroblast cultures from the same patient. This difference between the aberration frequency in vivo and in vitro may provide a clue to the nature of the inherited metabolic defect underlying Fanconi's anaemia.

We thank Thea Cohen for technical assistance.

SANDRA R. Wolman and Michael Swift

Departments of Pathology and Medicine, New York University Medical Center, New York, USA

\section{REFERENCES}

O'Riordan, M. L., Berry, E. W., and Tough, I. M. (1970). Chromosome studies on bone marrow from a male control population. British fournal of Haematology, 19, 83-90.

Pochedly, C., Collipp, P. J., Wolman, S. R., Suwansirikul, S., and Rezvani, I. (1971). Fanconi's anemia with growth hormone deficiency. Fournal of Pediatrics, 79, 93-96.

Sandberg, A. A. (1966). The chromosomes and causation of human cancer and leukemia. Cancer Research, 26, 2064-2081.
Schroeder, T. M. and Kurth, R. (1971). Spontaneous chromosomal breakage and high incidence of leukemia in inherited disease. Blood, 37, 96-112.

Swift, M. (1971). Fanconi's anaemia in the genetics of neoplasia. Nature, 230, 370-373.

Swift, M. R. and Hirschhorn, K. (1966). Fanconi's anemia. Inherited susceptibility to chromosome breakage in various tissues. Annals of Internal Medicine, 65, 496-503.

\section{Fanconi's Anaemia: Report of a Patient with Significant Chromo- somal Abnormalities in Bone Marrow Cells}

In Fanconi's anaemia, the presence of frequent chromosomal aberrations in cultured peripheral lymphocytes is now an established phenomenon. In fact, a number of authors (Bloom et al, 1966; Swift and Hirschhorn, 1966; Hirschman et al, 1969), suggest its demonstration as a valuable aid in establishing diagnosis in doubtful cases. On the other hand, very few instances of the above disease have been encountered in which similar changes were seen in bone marrow cells. The following communication describes one such patient.

\section{Methods}

Routine haematological investigations were carried out on blood and bone marrow aspirates according to standard methods.

Chromosome studies were performed on a peripheral leucocyte culture following the method of Moorhead et al (1960). One hundred consecutive metaphases were examined in detail. In addition, a bone marrow specimen obtained by sternal puncture was prepared for karyotyping using a slight modification of the technique of Tjio and Whang (1962). Ninety suitable spreads were photomicrographed and analysed.

\section{Case Report}

The patient, an 11-year-old male, was first seen at the paediatric service at the American University Hospital in September, 1966. His symptoms dated back to the age of 4 years, when he started having repeated attacks of easy bruising and bleeding from various sites (nose, urinary tract, rectum, and retina). Meanwhile he was noticed to develop progressive pallor which was not commensurate with the amount of blood loss. There was no history of exposure to drugs or bone marrow toxins.

The family history disclosed consanguinity in the

Received 11 April 1972. 